WHOI $-79-53$

\title{
AQUACULTURE DEVELOPMENT IN RURAL ATOMISTIC SOCIETIES
}

by

James R. McGoodwin

WOODS HOLE OCEANOGRAPHIC INSTITUTION

Woods Hole, Massachusetts 02543

June, 1979

\section{TECHNICAL REPORT}

Prepared with funds from the Pew Memorial Trust and by the Department of Commerce, NOAA office of Sea Grant under Grant \#04-8-M01-149, and the Institution's Marine Policy and ocean Management Program.

Reproduction in whole or in part is permitted for any purpose of the United states Government. This report should be cited as: Woods Hole oceanographic Institution Technical Report WHOI-79-53.

Approved for Distribution $\frac{\text { Rolut } h \text {. Werse }}{\begin{array}{l}\text { Dr. Robert W. Morse } \\ \text { Associate Director and Dean } \\ \text { of Graduate Studies }\end{array}}$ 
TABLE OF CONTENTS

Page

Abstract . . . . . . . . . . . . . . 3

1. AQUACULTURE DEVELOPMENT IN RURAL ATOMISTIC SOCIETIES • . • . • • • 4

2. WHAT IS AN ATOMISTIC SOCIETY? . . . . . . . 5

3. AQUACULTURE INNOVATION: SOME PRELIMINARY CONSIDERATIONS • . . . . . . 8

4. PLANNING AQUACULTURE DEVELOPMENT IN AN ATOMISTIC SOCIETY IN RURAL MEXICO • • • • 12

5. WOULD THE TEACAPANENึOS ADOPT HOUSE-SITE PONDS? . . . . . . . . . .

6. PLANNING AQUACULTURE DEVELOPMENT IN TEACAPAN . . . . . . . . . . . 25

7. CONCLUSION • • . • • . • . • • . . 26 


\section{Abstract}

For technological innovations to succeed in alleviating problems of rural underdevelopment they must be appropriate to the sociocultural context in which they are to be developed. Technical and economic feasibility alone is not enough. Atomistic rural societies--which are societies lacking in suprahousehold organizational entities--are the most common societal type found in the impoverished rural regions of the less developed countries. Development efforts in such societies and especially those where shortage of food is an acute problem, should aim first at intensification and regularization of domestic food production by increasing the productivity of households. When considering aquaculture development, family-operated, housesite, subsistence-oriented ponds, which employ rudimentary technology, would seem an appropriate innovation in atomistic communities. The author's field experience in an atomistic community in rural Mexico provides perspectives for the discussion.

\footnotetext{
Note: This paper was originally prepared for presentation for the Workshop on Aquaculture, sponsored by the International Federation of Institutes for Advanced Study, Ulriksdals Slott, Solna, Sweden, which was held at Woods Hole Oceanographic Institution, Woods Hole, Massachusetts, March 19-21, 1979.
} 


\section{AQUACULTURE DEVELOPMENT IN}

RURAL ATOMISTIC SOCIETIES

The alleviation of problems of rural underdevelopment and the stimulation of economies in impoverished rural regions calls for more than the consideration of technological and economic feasibility. Any innovation must also be appropriate to the specific sociocultural milieu in which it is to be developed.

Appropriate development must consider a variety of factors-technological constraints, the needs of the people, alternative courses of action, sociocultural attributes, and so forth ( see Pillay, 1977 and Pollnac, 1978, for a good general discussion). Berg (1975) stresses that "solutions which appear theoretically sound from a distant lab often turn out to be unfeasible in the context of the highly personal, highly traditional and socially motivated... habits of developing societies..."

One maxim that emerges from studies of the theory and practice of development in poor rural regions is that the basic nature of the society-its social, economic, and political organization, important patterns of belief and custom--must be identified. The existing sociocultural framework can then be incorporated into a development plan, and used to advantage. Indeed, many developmental projects have failed because they ignored the fact that a community may differ from expectations or assumptions held by those charged with developing, whereas others have succeeded through integration with the existing pattern. In this paper, I consider aquaculture development in an impoverished, rural, atomistic society. 


\section{WHAT IS AN ATOMISTIC SOCIETY?}

An atomistic society is one characterized by atoms rather than molecules, that is, a society notably lacking in organizational units which incorporate a large number of societal members or bring these together for collective action. In other words, the organizational pattern of an atomistic society is non-organization, disarticulation, etc. This descriptive tag was probably coined by the anthropologist Ruth Benedict in her 1942 Columbia University seminar on culture and personality (cf. Honigmann 1968:227, note 1), although the idea and central rationale-the individuation of collective society by imposition of wage-labor production modes--appears frequently in the writings of Engels (1845) and $\operatorname{Marx}(1847)$.

The best modern description and discussion of the atomistic society appears in a series of articles by Rubel and Kupferer et al. (1968: 189-235) . For them, atomism is characteristic on two important levels: structural and psychological. Structurally, the household is the main social and economic unit, the main arena for socialization and interpersonal security, and there are few other supra-household organizational entities. Thus, it is upon his household that the individual must rely for most of his basic needs. Each household, as Hunt and Nash (1967) note, operates as a small, independent economic firm, which collectively provides for the welfare of its members, and also sees itself in competition against all other households, producing what Banfield (1958:89), in The Moral Basis of a BackwardSociety called a society of "amoral familists." Structurally, atomism may be particularly extreme in societies which lack collective ritual or traditions, or where these traditions have been eroded by the society's 
exposure to modern, secular life, or where there is no effective political or leadership structure and the society is a mere political dependency of some larger unit, such as a head town in the region. Most often we encounter structural atomism in societies in which traditional subsistence systems have broken down, and where there is a high degree of dependency upon wage labor. To varying degrees, the foregoing conditions are characteristic of most of the small impoverished, rural communities of the less developed countries.

Psychologically, members of atomistic societies manifest extreme individualism, great reliance upon household members, and general distrust of others outside the household, even close kinsmen or other relatives. Invidiousness, suspicion, contention, societal disaffection, and so forth, are usually normative value orientations. Reluctance to join in cooperative social and economic activities is one manifestation of psychological atomism which has particularly confounded rural development.

Modern-industrial societies are atomistic in some ways, since they do have impersonal and individuating wage-labor systems, and also produce their share of alienated, disaffected individuals. But what most distinguishes an atomistic rural society in the developing nations from modern societies is the former's lack of supra-household economic organizations. If nothing else modern industrial society is characterized by a high degree of economic organization.

Among many sociocultural anthropologists, just what causes the existence of hyper-atomistic rural societies in the developing nations is a matter of conjecture. Mintz and Wolf (1950:196), and Harris (1971:322), 
stress the individuating effects of wage-labor production, which arise out of intense competition for impersonally awarded jobs, and lead to a breakdown of traditional mechanisms of socio-economic integration: those based on kinship and ritual kinship, for example. Rubel and Kupferer (1968:190) focus upon incongruities in the socialization process where individuals are socialized to rely solely upon household members and to distrust all others, but as adults, must seek the most important social and economic ties (marital partners and employers) outside the household. Redfield (1947:30) attributes atomism to loss of tradition and secularization or commercialization of folk festivals, where institutions of folk culture "become business enterprises in which individuals take part for secular ends." Lewis (1966), in "The Culture of Poverty", emphasizes how poverty is conducive to many forms of non-idyllic attitudes and behavior--behavior which perhaps can be regarded as "rational" given certain objective conditions. The causes of social atomism are numerous and complex, but its existence in a majority of rural societies in the less developed countries, particularly in what are generically known as "peasant societies", is far from conjectural. Speaking of the poor quality of social relations observed in most peasant societies, Rubel and Kupferer(1968:189) stress that "the quality of interpersonal relations... is not in dispute.. They are, in fact, a phenomenological reality... the data exist "out there", not in the mind of the observer."

The rural, atomistic society is the most pervasive type of society in the developing world, particularly in many parts of Latin America and Asia. In this paper I exclude from consideration a number of other common societal 
types encountered in the less developed countries because they comprise only a minority of societies: "primitive","preliterate", and/or isolated tribal peoples, for example; closed corporate, peasant communities, organized around and steeped in collective traditions having long-term continuity; communal or utopian societies; and plantation societies--rural communities organized under large-scale business or governmental auspices.

\section{AQUACULTURE INNOVATION: SOME PRELIMINARY CONSIDERATIONS}

Some aquaculture developers distinguish between aquaculture development aimed at alleviating subsistence problems versus development aimed at increasing individual cash incomes and stimulating local and regional economies. Proponents of development designed to generate income maintain that innovations which increase personal incomes are necessary for the people to become truly modern, or developed, and that projects aimed solely at alleviating subsistence problems over the long run tend to insure the people's continuance in poverty, keeping them separate from participation in the market economy of the nation and the world. I find that argument somewhat specious; in rural areas where nutritional deficiency is the leading problem, I feel that it is the problem which should be attacked first.

Studies of development have shown that increasing food production will not guarantee an increase in local food consumption. In the fisheries of many developing nations, for example, much of the most desirable production is exported to developed nations which are not short on food. In protein-deficient Latin America (Argentina excluded), over $2 / 3^{\mathrm{\prime}} \mathrm{s}$ of the total fish catch is exported (Allsopp and Palacio 1977:311), and even in Mexico--Latin America's most developed nation--food shortages have become so acute in many rural areas that they are causing the infant mortality rate to 
rise for the first time in decades. Dr. Adolfo Chávez, Director of the National Nutrition Institute in Mexico City, cites numerous rural communities where few children borm since 1974 have survived, leaving what he calls "generational holes" (Chávez 1978). Providing food should be the paramount order of business, but it must be treated in a different manner from the increase of food production per se (see Lappé and Moore 1977, and Berg 1975, concerning the primacy of addressing nutritional shortages in the less developed countries).

In the case of aquaculture development, as we ascend the scale of complexity from subsistence-oriented to income-producing systems we note an almost exponential growth in problems which threaten feasibility. The problems of large-scale, vertically-integrated aquacultural enterprises-those aimed at developing crustacean aquaculture, for instance--now seem insurmountable for rural-atomistic societies. Such projects initially require considerable capitalization, an ability to operate at a loss temporarily, and a degree of managerial expertise, technological sophistication, and biological control which is far beyond the capabilities of members of rural atomistic societies (see Webber 1975, Webber and Riordan 1976, and Matsuda 1978:2).

The development of aquaculture in impoverished, rural-atomistic communities must take into account several factors. First, of course, are technological factors: is the soil right, is the water good, can suitable species be easily obtained, etc.? Determining technical feasibility is not an easy matter, but it is that aspect of aquaculture development about which the most is already known, and there are a growing number of skilled technicians in most developing nations who can provide the service.

But beyond determination of technical feasibliity, there must be a 
consideration of human factors: sociocultural patterns, political structure, economic organization, even how individuals feel about life and work. No definitive methods have been developed for studying these aspects of human society, but they must be investigated, since many developmental projects have failed because of neglecting them. Cordell (1973:31), for example, detailing how modernization of Brazilian coastal fisheries ultimately impoverished thousands of rural fishermen, states "no one bothered to ask how the traditional fishing system worked... how production was organized in local communities, or what impact (modernization) would have on resources." In the case he describes, important technological innovations fell into the hands of wealthy middlemen, factory bosses, plantation owners, and local merchants--people who could afford to speculate. The remaining traditional population did not reject these innovations; they simply could not arrange the loans necessary to acquire them. And similar case histories abound. Munch $(1947,1964,1970)$, for instance, in a now classic case describes how in Tristan da Cunha a people with a long-standing tradition of egalitarian cooperation rejected "progress" in the form of modernized fishing production because such production required submitting to contract relationships, which the local people felt was an infringement upon traditional core values. Among them, the ethos of industrialism was either rejected, or was accepted only in second place to independence, individual integrity, and selective reciprocity, the core values in their society.

The core socioeconomic values in an atomistic society are selfsufficiency, individualism, reliance upon household members for economic security, and avoidance of encumbering relationships with those outside the household. 
little chance of success. Nakamura (n.d.), for example, notes that certain aquacultural innovations among the impoverished Lummi Indians of Washington state were successful where they enhanced the existing sociocultural system and reinforced long-standing traditional values, whereas other innovations not thus integrated fared rather poorly. He urges the development of technological innovations which improve rather than displace traditional methods. The Lummi had a strongly communal society, so in their case a group-wide developmental effort ras appropriate. In an atomistic society, on the other hand, such efforts would be inappropriate, and it would seem better to first try to strengthen the "atoms" in such societies (individuals/households) before predicating developments upon the functioning of "molecules" (working groups, which simply do not exist).

In order to achieve a good understanding of the feasibility of certain developments we must live in the society to be developed for protracted periods of time, gain an understanding of how things economic are embedded in things social, learn the systematic relationships of distribution and redistribution of goods and services, determine the economic ramifications of the kinship or ritual kinship systems, determine how goods are allocated for subsistence versus market ends, and so forth. Therefore, fairly long-term protracted participant observation, which results in an intimate personal knowledge of the society to be developed, may ultimately be the most effective strategy a researcher interested in development can employ for determining what types of developmental innovations would be feasible, and how their development should proceed. 


\section{PLANNING AQUACULTURE DEVELOPMENT IN AN ATOMISTIC SOCIETY IN RURAL MEXICO}

Since 1971 I have lived from time to time in an impoverished, ruralatomistic community on Mexico's Pacific coast. Teacapan, in the state of Sinaloa, with about 2,600 inhabitants, is roughly 80 kilometers south of the urban port of Mazatlán. The people are Spanish-speaking rural mestizos who self-identify simply as Mexicanos, that is, as citizens of the Mexican nation. There are no indigenous (Indian) people living in this coastal area. Surrounding this community are labyrinthian systems of estuaries and briny lagoons, which are the rearing grounds for prodigious shrimp populations, and which formerly harbored a great abundance of other marine organisms important to man, especially oysters and fin fishes. Dry farming of both cash crops and traditional Mesoamerican crops is also practiced on the cleared lands in this coastal zone. Overall, the region is impoverished, with a population density of about 100 persons $/ \mathrm{km}^{2}$, which is fairly high considering that much of the land is uninhabitable wetlands, marshes, lagoons and swamps. This is a good laboratory for considering developmental innovations, since it has not only the usual sort of agriculture found in much of the developing world, but also fishing.

Living conditions in this region are very poor. Houses are crowded and lack water service and sanitary facilities; many households do not even have outhouses, their inhabitants eliminating where they may. Household garbage is scattered everywhere, especially in the dirt streets in front of the houses, where it is periodically raked into piles and partially burned. The town lacks potable water systems; drinking water is either bought from commercial vendors, or drawn from various brackish, and often polluted, shallow wells, The wells are important links in chains of infection causing 
the region's major acute chronic infections: amebiasis, gastroenteritis, and numerous other infectious and parasitic diseases. Onslaughts of biting insects are also a problem throughout most of the year.

House sites generally measure about 25 by 30 meters. To acquire a house site a head of household petitions the Federal government's Comisión Ejidal, asking for permanent use of a house site in the town's zona urbana. Use of ejido agricultural plots is obtained in the same manner, by petitioning for use of a plot in the zona rural. Sites in the zona urbana are still fairly plentiful, at least on the town's periphery, whereas agricultural plots in the town's zona rural have been fully subscribed for decades. A survey I conducted in Teacapán in 1974 indicated that household membership ranged from 2 to 20 members, with 6.2 members being the mean. About $70 \%$ of all households were nuclear in type, the remainder extended. The typical house is little more than a simple hut. Some huts are constructed of vegetable materials, with dirt floors, while others may have concrete floors, stucco walls, and perhaps a tin roof. Electrical services have been available since the late 1960 's, and all the huts have a least one or two electric lightbulbs. A few households also have small electrical appliances such as radios, mixers, or blenders. Furnishings are simple and inexpensive. Interior artistic decorations are limited to mostly photographs torn from magazines depicting film or recording artists. All huts front on the street and in the back yards there are usually a few fruit trees-banana, coconut, lime, papaya, and mango--a chili bush or two, a few pigs, and some chickens. Women and children are found in the house most of the day; the adult males are usually only present for meals, and in the evenings. 
Sex-role differences are marked and rigid. Women manage the households; men who are old enough seek wage labor work, pursue subsistence activities, or loiter about in town gossiping and drinking. Children either attend primary school or loiter about the huts, and nearly all day the town's streets are filled with playing children.

There is a very brittle quality to interpersonal relations in the community. Great suspicion regarding the motives and affairs of others is normative in social relations, and expressions of distrust, envy, invidiousness, and disaffection are commonplace. There is also widespread alcoholism, especially among men. Thievery and violence occur frequently.

The town has no effective local leadership. It major administrative needs are handled by officials in the head town 40 kilometers away. A few short-term appointees from the head town usually live in Teacapan for up to a year. The town president is usually a local person who is coerced into taking the post for a year by a politician in the head town. There are few potential leaders in this community. Most of the town's affluent families have moved away to distant urban centers, leaving behind overseers and managers to staff their various enterprises: shops in the town, landholdings upon which cash crops and cattle are raised, and in some cases fishing boats.

For most of the people of Teacapán, life is a difficult, protracted struggle: $86 \%$ of them depend upon sporadic wage-labor work--either in agriculture or in fishing--in order to earn the cash necessary for life's necessities. 
There always is an abundance of workers eager to take the available jobs, a situation which contributes greatly to the community's strained interpersonal relations.

In order to provide their family's food needs during the frequent intervals of unemployment, household members engage in primary subsistence activities, and among these there are two main types. The most important is individualistic subsistence fishing activity in the region's estuaries and lagoons, an activity which only rarely yields a surplus production which might be sold for cash. Fishing activity is almost solely the province of males--from the adolescent to the elderly. The second, and less important subsistence strategy, is mall-scale animal husbandry carried on around the house sites. This activity is mainly the province of the household's women, and the most important production is eggs, as well as some meat from the poultry. Occasionally a household may produce more eggs than it can consume in a day, and sell the surplus, but eggs are a main food item in most households and there are rarely enough. A few pigs are also usually tended by the adult women, not for food needs, but as a "savings account", something which can be sold quickly to a local butcher when cash is short.

Summer is the most difficult season of the year. Then fishing production reaches its lowest ebb and there are no significant agricultural harvests. At the same time, there is little wage-labor work to be found. It is a desperate time for many; no food, no money. In the summer months I have seen children eat spoonfuls of dirt or sand, trying to mitigate their gnawing hunger. The local people have a saying about summer: "En agosto, mucho león", which means "In August (there are) lots of (hungry) lions, i.e. thieves". The pervasive nutritional disease in this region is obvious to any observer. The town does have one significant supra-household organization: a 
fishing cooperative, which until a decade ago was fairly prosperous, but now has all but ceased operation. Instituted by the federal government in the 1930's --Mexico's era of post revolutionary reforms-- the cooperative was granted exclusive rights to fish in certain productive parts of the surrounding lagoons and estuaries. Shrimp production for the international export market was, and remains, the cooperative's raison d'être. Initially prosperous, the cooperative, like its rural counterparts all along this coast, has become a marginal enterprise. Now it must compete with highly mechanized, urban based, trawler fleets which also produce marine shrimp. Over the past two decades these fleets have become economically preeminent in the Mexican shrimp industry. Moreover, as the trawler fleets have grown, the federal government has increasingly restricted inshore shrimp harvesting so that more of the crustaceans--which spend the middle part of their life cycle in inshore lagoons--will return to the sea, spawn, and then be captured by the offshore trawler fleets. Today the inshore cooperatives are permitted only 2 weeks of shrimp production at their fairly simple lagoonal weirs, whereas the offshore trawlers are permitted to harvest shrimp for 35 weeks of the year.

All sanctioned shrimp production along the Mexican Pacific Coast is carried on by government-instituted enterprises. No free-enterprise shrimp fishing is permitted, and even subsistence-oriented shrimping is greatly constrained. Thus, the rural fishing cooperatives are the only organized entities having rights to harvest shrimp. But aggravating the rural cooperative's situation is caciquísmo, or corrupt political-economic bossism. Venal burinessmanpoliticians in the region have appropriated the cooperatives' production for their personal gain, relegating the cooperativistas to mere shift laborers, denying them the participation in the management of the cooperative's internal affairs that is supposedly guaranteed in the organization's charters. 
Teacapán's cooperative also used to produce large volumes of oysters and fish,but the regions's oysters were almost totally destroyed by a disastrous flood in the late $1960^{\prime} \mathrm{s}$, and the once prodigious inshore fish stocks were overfished about a decade earlier with the introduction of motorized boats and nylon nets in inshore fishing. Continuing subsistence pressure by the regional population has never permitted either of these resources to recover. Today's net fishermen now rely on harvesting secondary species, so-called "trash fish", which are converted into fish meal.

In the 1960's the Mexican federal government undertook dredging projects in the inshore regions to increase the inshore cooperative's shrimp production, and also began mariculture projects aimed at increasing oyster production. These efforts were partly successful but had little effect on the overall economy of the area because the fishing cooperatives only incorporate about $2 \%$ of the regional population, and for even that $2 \%$ the income from cooperativized fishing barely competes with wages paid to agricultural laborers.

Thus, Teacapán's local fishing cooperative would not be an appropriate, existing socioeconomic organization out of which to develop aquaculture. The mariculture projects completed in the 1960's, especially those aimed at stimulating shrimp and oyster production, brought such production near the limits of its potential growth, while not incorporating much of the local population. Moreover, among the $98 \%$ of the regional population which is not in any fishing cooperative, the cooperatives are viewed pejoratively, as government businesses (which indeed they are) run by the government for the benefit of a few politicians and a minority of cooperativistas. And the cooperativistas themselves cannot exercise effective control over the marketing of what they produce, since the cooperative's charters specify that they 
must turn over all their (exportable) production to a central, governmentowned packing plant, and then be paid whatever prices the govermment has established for the particular season. Thus, for both the $2 \%$ of cooperativistas and the rest of the regional population, the local cooperative is viewed with distrust, antagonism, or disillusionment, especially by the region's countless subsistence fishermen, who risk federal prosecution when fishing in territories set aside to the cooperatives. Marine-capture fishing in Teacapán's region is overdeveloped and overutilized, and unless the federal govermment radically changes its fisheries management policy by reorienting production away from the international market and toward regional subsistence needs, further development of marine-capture fishing in this region would seem unlikely. However, the government is not likely to change its policy.

The first step in considering aquaculture development in a community such as Teacapán is to identify the people who need such an innovation. Looking at the community again, $86 \%$ of the populace is wage dependent, while the $14 \%$ that is not wage dependent includes various town dwellers who run small shops, corner grocery stores, a pharmacy, a barber shop, or perhaps function as brokers of fishing and agricultural production. This latter group includes a few of the town's affluent residents. This $14 \%$ seems the least in need of aquacultural innovations, since they have the most ready access to both food and cash, and are already practiced in the ways of business and commerce. Rather, the wage dependent $86 \%$ seem to be the most in need.

Of the wage dependent population, approximately $44 \%$ occupationally specialize in fishing, and $42 \%$ in agriculture. The rigidity of occupational 
specialization is fairly high in the case of fishermen, less so in the case of agriculturists. Fishermen seem particularly averse to agricultural work, pursuing their livelihoods through a combination of subsistence fishing and wage-labor work aboard local fishing boats.

The town's agriculturists include two main types: ejidatarios, or farmers of small plots awarded to them by the Comisión Ejidal, and jornaleros, a slightly larger group, who are landless agricultural laborers. Jornaleros frequently engage in subsistence fishing during hard times or when marine resources are plentiful, but this is not to suggest that the ejidatarios are much better off, since both types of agriculturists are highly dependent upon incomes from wage-labor work in regional agriculture.

All three groups-fishermen, ejidatarios, and jornaleros-- suffer poverty; all are beset by times without food or work, especially in the summers. What they most need is a food bank, where they could store protein-rich foods for the bad times. Hence, small, family-operated aquacultural ponds seem a possible solution. Through development of such ponds, the local population of Teacapán might within a few years be able to say "En Agosto, contamos con los pozos", or "In August we count on our ponds." The development of such ponds should be one component of a comprehensive, multifaceted project aimed at intensifying household food production. The technology described by Chakroff (1976) in a Peace Corps/V.I.T.A. technical assistance manual, as well as that developed by the New Alchemists (see Todd 1977), integrating house-site agriculture, animal husbandry, and aquaculture, would seem appropriate for Teacapán and similar communities.

Why small, family house site ponds? Mainly, because the households are the economic firms in this society, and thus the most likely avenues for development which would capitalize upon the existing sociocultural organization. 
And, small-pond aquaculture seems technologically feasible for Teacapán. There is an abundance of water from the region's shallow wells. That water would require purification, and although it is slightly briny it should be suitable for the production of tilapia or gourami, both good species for the novice fish farmer. There is also an abundance of animal excrement and organic materials available, and the region's large insect populations seem a likely source of foodstuffs for the fish. For Teacapán, the major technological problem would be sealing the ponds, since most of the house sites are built on porous sands.

Below I summarize several reasons why family house-site aquaculture ponds sem to be an appropriate strategy for development in Teacapán:

1. Site availability: In Teacapán every family has an entitlement to a house site, and enough town sites are still vacant to accommodate the community's projected population growth for two or three decades.

2. Security: Thievery is a serious problem in this community. Housesite ponds would be more secure than ponds developed outside the community, since somebody is home nearly all the time. Webber (1973:169) cautions that thievery of fish from aquafarms in Honduras is a serious problem, and he warns about the prohibitive costs of hired watchmen, dishonest watchmen or managers, urging ponds instead be established in regions having low population density. Of course, low population density is not an attribute of very many rural areas in the less developed countries.

3. Compatibility with the community's atomistic economic structure: Individual households are the economic firms in this local society, which lacks larger economic groups. 
4. Compatibility with economic activities of households: All families-fishermen, ejidatarios, and jornaleros-- already practice small-scale animal husbandry and grow a few fruit trees and other plants at their house sites. The ponds would require only a small amount of additional labor.

5. Low initial investment: A family pond would require a relatively small investment per family, with most of the investment being labor in constructing the pond. Simple ponds do not have to limit families to mere subsistence living. With proper and enterprising management, successful pond owners will likely produce a surplus which they can sell to local fish brokers. Any developmental project aimed at introducing house-site ponds should also provide educational assistance to show people the possibilities for expanding and marketing their production.

6. Management: The ponds could be managed by the household's women as part of their animal husbandry activities. A crucial problem in many households is the absence--either periodic or permanent-- of adult men who might bring home cash and food. This problem is particularly acute in the families of fishermen, where periodic abandonment of the household by the adult males is commonplace or where the adult males are transient much of the time. This pattern is fairly common in poor fishing communities around the world, with the result that community households are typically maintained by a core of adult women--the so-called "matrifocal" family. Typically, such families consist of a woman, her children, and often her mother, her sister(s), and sister's children. There are many such households in Teacapán.

Reliance on the women to manage the house-site ponds may place a great burden on the already hard working women of Teacapán, but they seem the only likely managers of such ponds in their local society. Developmental efforts in Teacapán should encourage the society's adult males to play a more active role in house-site food production, but that would require such a radical change 
in the existing norms for sex role behavior that it is doubtful whether much progress would be made initially.

\section{WOULD THE TEACAPANENNOS ADOPT HOUSE-SITE PONDS?}

The foremost problem facing the Teacapaneños is hunger. Aquaculture development should start by addressing a people's most pressing problems, and then work outward. Even if the family house-site ponds proposed here never earn income, they might alleviate hunger and periodic food shortages. On the other hand, developments which aim at generating income will only alleviate such people's miseries if successful; if they failed they would cause great financial losses. Indeed, increasing family incomes may not be desirable in Teacapán society, since in many families, and particularly fishing families, influxes of cash are quickly squandered by the men in drinking parties with their other male friends. Changing an entire society's attitudes about cash income, entnepreneurship, sex roles--indeed, their whole lifestyle-would require a long-term and massive effort, the scope and complexity of which is beyond the conjectural skills of this author. In any event, such an undertaking would require many years, and meanwhile people would go on being hungry.

Whether aquaculture innovations will take hold in Teacapán's local society, or others like it, depends upon the Teacapaneños themselves and the usefulness of the innovation to them. Here all three of the major impoverished and wagedependent groups might adopt family house-site ponds, but in differing degrees. The ejidatarios would probably be the most willing to try it, since they are already accustomed to farm-type production, animal husbandry, long-term economic planning, and have some experience--although not all favorable-with regional extension agents and lending institutions. 
The jornaleros (day-wage laborers in agriculture) might not be so willing to build and operate ponds. Jornaleros are familiar with agricultural production modes and also with animal husbandry, but they are also accustomed to short-term rewards arising from wage work or occasional fishing activity, and not accustomed to long-term efforts which require ongoing supervision. Most of them have no experience with extension agents, lending institutions, or other institutional operatives. Nevertheless, they suffer the same food shortages as the rest of the people, and do have house sites upon which small ponds could be developed.

Whether the community's fishermen would develop house-site ponds is doubtful. Their families do have sites available, already practice smallscale animal husbandry, and suffer periodic food shortages, so from those perspectives they seem likely candidates. However, as an occupational subgroup--and perhaps subculture--they are markedly different from their agricultural counterparts in temperament and main value orientations, particularly those values having to do with work. Their pride in being free and unencumbered is a central value underlying their whole lifestyle. Statements like the following, describing how they feel about life and work, are common among the town's adult male fishermen:

Fishing is the best life because it is the most free way one can live, and also because it brings the most money. I do not have to plant or plow in the lagoons, and you will never see me working like an animal in the fields. When there are fish I take them, and when there are not I enjoy my compañeros (male companions: drinking companions). The farmers around here are made old while 
still very young because their work is so hard. Work in the fields makes them dull and stupid. They never have any money, work all the time, cannot tell jokes like we fishermen, and hardly ever buy alcohol for their compañeros. They never go anywhere except to their milpa (agricultural plots) or their huts.

Among the fishermen I have interviewed in Teacapán, not one said he ever went to the United States during the bracero program, 1942-1945, even though in many purely agricultural settlements in Mexico nearly every adult male made at least one journey to work in agriculture in the United States (see Foster 1967). This fact alone underscores the attitude of Teacapán's fishermen toward agricultural work of any kind, and because aquaculture production is more like agriculture production than marine-capture fishing, they might view aquaculture negatively.

In a survey where I asked fishermen to characterize the difference between themselves and their agricultural neighbors, I obtained results almost identical to those obtained by Pollnac (1977a and 1977b), who interviewed rural fishermen in a coastal region of Costa Rica. The Teacapán fishermen emphasized that the main difference between themselves and their agricultural neighbors was money; nearly all reported preferring fishing because they felt they made more money than the farmers, stressing the relatively great quantities of money that one fisherman might earn in just one or two successful days of fishing. This may be a mythical rather than a realistic view of such income. In any event, since they would likely not perceive family house-site ponds as capable of generating income in the same way as marine-capture fishing, there is little reason to think the fishermen would be enthusiastic about the development of such ponds. Indeed, suggesting they should produce fish from ponds 
might be perceived by many fishermen as a threat to their fishing prowess. Thus, whether or not the town's fishing families would adopt house-site subsistence ponds seems problematic. In the first phases of development one should determine whether the fishing families' women would adopt the innovation, while the men would be at least passively accepting.

\section{PLANNING AQUACULTURE DEVEIOPMENT IN TEACAPÁN}

There are many ways to evaluate the suitability of a developmental program for a specific area. These include the commonly employed measures of social scientists--economists, sociologists, anthropologists, psychologists, etc.-and range from simple methods such as surveys which ask direct questions (e.g. "would you like to see a small fish pond established on your house site?") to more sophisticated methods which explore sociocultural factors, such as self and occupational concepts, and so forth. I urge a simple and direct approach, but employment of more sophisticated methods, assuming there is the necessary time, money, and skilled and willing investigators available, should also be undertaken if possible (see Pollnac's (1977b) use of semantic differential tests among coastal costa Ricans, which resulted in useful information about occupational concepts, and also his papers on aspects of psychocultural adaptations to marine environments (1976: 32-94); see also applications of the methodology of ethnoscientific elicitation and analysis, which the author (1976) found efficacious in exploring self concepts in the "alien" realm of an alcoholic's cognitions). Whatever the method, to determine whether or not an innovation will fit, you must determine the central values the people hold about themselves, their neighbors, interpersonal relations, 
and economic life, which in rural societies are often embedded in the whole social fabric.

\section{CONCLUSION}

Nothing can substitute for commitment and involvement on the part of the developers, yet it is in this crucial area that most developmentalists fall short. There are plenty of highly trained people who are knowledgeable about rural underdevelopment and aquaculture technology, but few are sufficiently sensitive to the nuances of sociocultural patterns which may ultimately doom an otherwise promising project to failure. This sensitivity can be gained only by living among the people to be developed for a long time.

Rural development requires a rare type of professional, one who has not only the requisite knowledge, but who is also willing to spend a few years in the developing region. A minimum of a year should be spent developing familiarity with a local society and culture and gathering basic socicultural data; another year to initiate pilot projects; and finally another two or three years to see the innovations through the stage of acceptance and takeoff. Who will spend that amount of time in impoverished regions? Tropical coastal regions in particular are extremely difficult environments in which to live, and it is not surprising that they have been neglected by development specialists and other applied social scientists. These regions usually have higher incidences of disease than adjacent highland regions, and often more insects, water shortages, and environmental hazards such as hurricanes and flooding. Anthropologists in Mexico, for example, have long thronged to the aesthetically pleasing, cool, highland areas, especially those inhabited by indigenous peoples who wear beautiful 
costumes and make colorful craft items. But correspondingly few have spent much time in Mexico's torrid coastal areas, and I suspect this is more or less true of the incidence of developmental effort worldwide.

Rural development must begin by addressing crucial needs, and then build a solidly established base of modest successes. But there seems to be a short supply of the special breed of professional who has the skill, experience, and willingness to make a long-term commitment to the peoples to be helped. Perhaps the development of such professionals should be rural development's first priority. 
REFERENCES CITED

1977 Allsopp. W.H.L., and Francisco J. Palacio, "Reflections on Interciencia Marine Science Symposium, "Interciencia $2(5): 311-313$.

1958 Banfield, Edward C.

The Moral Basis of a Backward Society. Glencoe, Illinois: The Free Press.

1975 Berg, A. "Nutrition as a National Priority: Lessons from the India Experiment", In PAG Compendium (Vol.F): 309-336. New York: Worldmark Press.

1978 Chávez, Adolfo

Cited by Editors, Behavior Today (March 20): 3 .

1973 Cordell, John C.

"Modernization and Marginality," Oceanus 17 (5): 28-33.

1845 Engels, Frederich

Conditions of the Working Class in England.

1967 Foster, George M.

Tzintzuntzan: Mexican Peasants in a Changing World. Boston: Little, Brown, and Company.

1970 Fromm, Erich, and Michael Maccoby

Social Character in a Mexican Village: A Sociopsychoanalytic Study. Englewood Cliffs, New Jersey: Prentice-Hall

1971 Harris Marvin

Culture, Man and Nature: An Introduction to General Anthropology. New York: Thomas Crowell. 
1968 Honigmann, John J.

"Interpersonal Relations in Atomistic Communities," Human Organization 27 (3): 220-229.

1967 Hunt, Eva M., and June Nash

"Local and Territorial Units, "In Manning Nash, Vol. Fä., and Robert Wauchope, Gen. Ed., Handbook of Middle American Indians, Volume 6, Austin: The University of T'exas Press.

1977 Lappé, Frances Moore, and Joseph Collins Food First: Beyond the Myth of Scarcity. New York: Houghton Mifflin and Company.

1966 Lewis, Oscar

"The Culture of Poverty", Scientific American 215: 19-25.

1976 McGoodwin, James R.

"Ethnosemantic Analysis of Cognition in the Alcoholic Patient", International Journal of the Addictions 11 (4): $619-628$.

1978 MicGoodwin, James R.

"No Matter How we Asked Them, They Convinced Us That They Suffer", Human Organization 37 (4).

1847 Marx, Karl

The 18th Brumaire of Iouis Bonaparte.

1978 Matsuda, Yoshiaki

"The Growth of Aquaculture in Developing Countries:

Potentials, Patterns, and Pitfalls", Fisheries 3 (4): $2-6$.

1950 Mintz, S.W., and E.R.Wolf

"An Analysis of Ritual Co-parenthood (Compadrazgo)", Southwestern Journal of Anthropology 6: 341-368. 
1947 Munch, Peter A.

"Cultural Contracts in an Isolated Community: Tristan da Cunha", American Journal of Sociology 53 (1): 1-8.

1964 Munch, Peter A.

"Culture and Superculture in a Displaced Community: Tristan da Cunha", Ethnology 3: 369-376.

1970 Munch, Peter A.

"Economic Development and Conflicting Values: A Social Experiment in Tristan da Cunha", American Anthropologist $72(6): 1300-1318$.

n.d. Nakamura Royden

"Aquaculture: Innovative Science and Technology in Poor Societies ", ünpub. us.

1977 Pillay, T.V.R.

Planning Aquaculture Development: An Introductory Guide. Published by arrangement with the Food and Agriculture Organization of the United Nations by Fishing News Books, Ltd., Farnham, Surrey, England.

1976 Pollnac, Richard B.

"Man"s Psychocultural Adaptation to the Marine Environment", pp. 32-94 In Continuity and Change in Marine Fishing Communities, Richard B. Pollnac, Ed., Kingston: International Center for Marine Resource Development, University of Rhode Island, July. 
1977a Pollnac, Richard B.

"Small Scale Fishermen's Perceptions of the Occupation

of Fishing in the Gulf of Nicoya, Costa Rica", Anthropology

Working Paper No. 18, Department of Sociology and

Anthropology, International Center for Marine Resource

Development, University of Rhode Island, July.

1977b Pollnac, Richard B.

"Variance in Perception of Fishing and Farming Among

Small Scale Fishermen in the Gulf of Nicoya, Costa

Rica", Anthropology Working Paper No. 20, Department of

Sociology and Anthropology, International Center for

Marine Resource Development, University of Rhode Island, November.

1978 Pollnac, Richard B.

"Sociocultural Factors Influencing Success of Intermediate

Food Technology Programs", Food Technology 32 (4): 89-92.

1967 Potter, Jack M., May N. Diaz, and George M. Foster (Eds.)

Peasant Society: A Reader. Boston: Little, Brown, and Company.

1947 Redfield, Robert

"The Folk Society", American Journal of Sociology 52,

January .

1968 Rubel, Arthur J., and Harriet J. Kupferer et. al.

"Perspectives on the Atomistic-Type Society",

Human Organization 27 (3): 189-234.

1977 Todd, Nancy Jack (Ed.)

The Book of the New Alchemists. New York: E.P. Dutton. 
1973 Webber, Harold H.

"Risks to the Aquaculture Enterprise", Aquaculture 2: $157-172$.

1975 Webber, Harold $\mathrm{H}$.

"Crustacean Aquaculture in Middle America", Marine

Fisheries Review 37 (1): 24-30.

1976 Webber, Harold H., and P.F. Riordan

"Problems of Large Scale Vertically-Integrated Aquaculture", Food and Agriculture Organization Conference on Aquaculture, Kyoto, Japan, May 26 to June 2, 1976, FIR: AQ/Conf/76/R. 4 (FAO Technical Reports). 
No. of Copies

3

1

5

25

\section{Address}

National Sea Grant Depository Pell Marine Science Library University of Rhode Island Kingston, RI 02881

Ms. Mary Holliman

Sea Grant 70's

Food Sclence Department

V.P.I. and S.U.

Blacksburg, VA 24060

Office of Sea Grant 6010 Execut1ve Boulevard Rockv1lle, Maryland 20852

ATTN: Dr. Nalda Yolen

Mrs. E. Downs

Acquisitions Section, IRDB-D823

L1b. \& Info. Serv. Div., NOAA

6009 Executive Blvd.

Rockv1lle, Md. 20852 


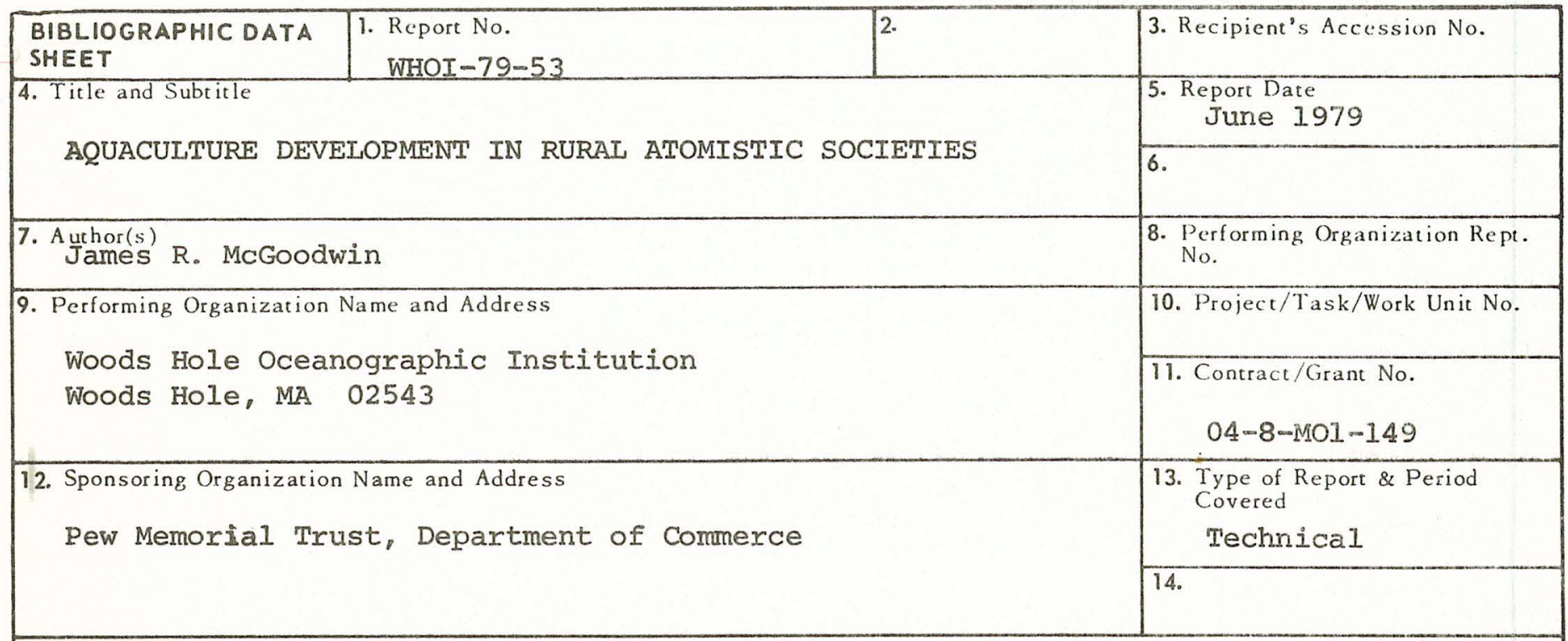

15. Supplementary Notes

16. Abstracts

For technological innovations to succeed in alleviating problems of rural underdevelopment, they must be appropriate to the sociocultural context in which they are to be developed. Technical and economic feasibility alone is not enough. Atomistic rural societies-which are societies lacking in supra-household organizational entities--are the most common societal type found in the impoverished rural regions of the less developed countries. Development efforts in such societies and especially those where shortage of food is an acute problem, should aim first at intensification and regularization of domestic food production by increasing the productivity of households. When considering aquaculture development, family-operated, housesite, subsistence-oriented ponds, which employ rudimentary technology, would seem an appropriate innovation in atomistic communities. The author's field experience in an atomistic community in rural Mexico provides perspectives for the discussion.

17. Key Words and Document Analysis. 17a. Descriptors

1. Aquaculture

2. Rural development

3. Atomistic societies

17b. Identifiers/Open-Ended Terms

17e. COSATI Field/Group

18. Availability Statement

19. Security Class (This
Report)
UNCLASSIFIED

21. No. of Pages

32

22. Price 


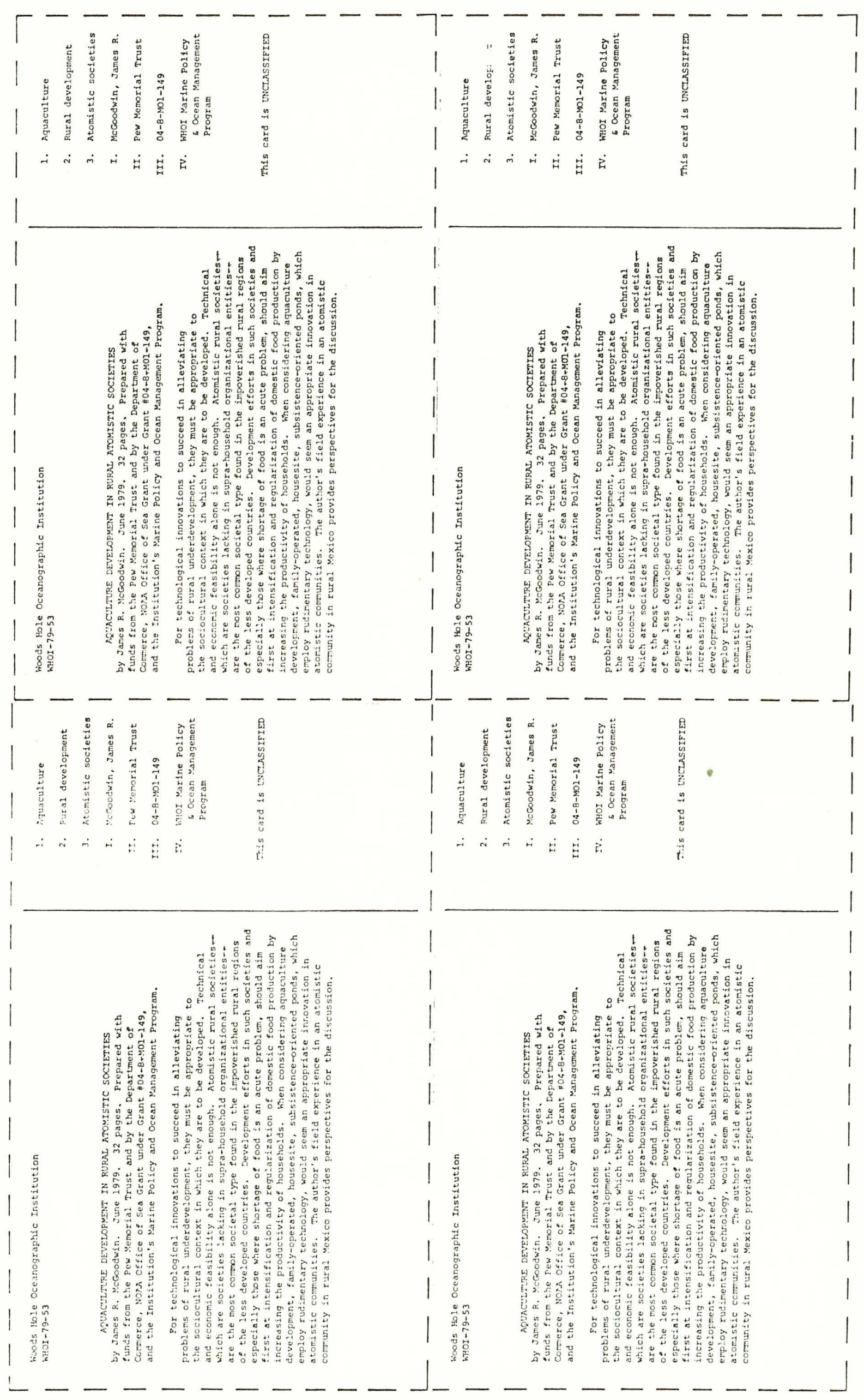

